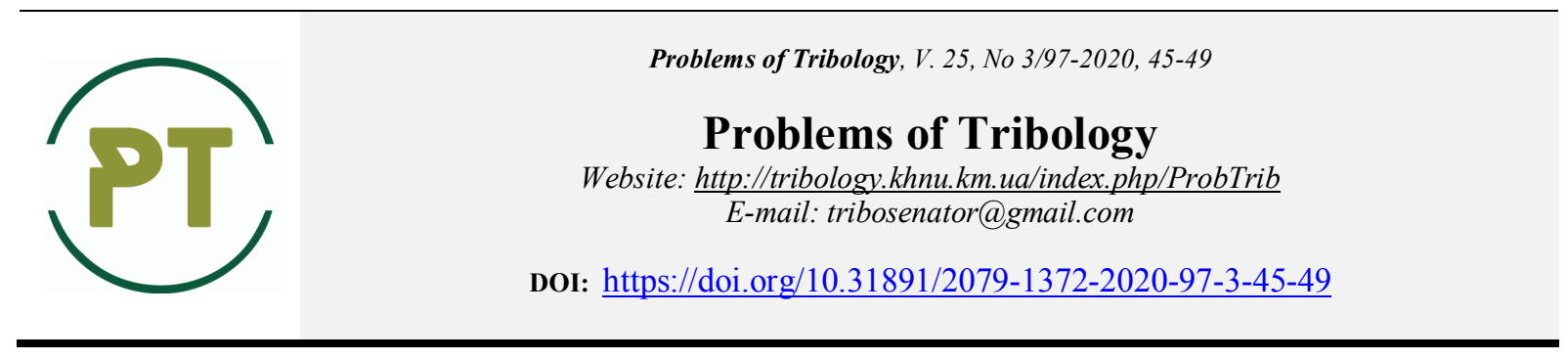

\title{
Modeling the processes of friction and wear under dynamic influences on the tribosystem
}

\author{
A.V. Voitov \\ Kharkiv Petro Vasylenko National Technical University of Agriculture, Kharkiv, Ukraine \\ E-mail:K1kavoitov@gmail.com
}

\begin{abstract}
On the basis of the performed analysis of works devoted to the increase in the wear rate due to the dynamic effect on the tribosystem, expressions were obtained for modeling the processes of friction and wear when changing the external influence. Based on the assumption that the dynamic impact obeys the normal distribution law, the coefficient of variation of the volumetric wear rate. The simulation of the change in the coefficient of variation when changing the load and sliding speed on the tribosystem, as well as the number of steps of changing the load and operating time at each stage.

It was found that in the absence of fluctuations in the load and sliding speed, the coefficient of variation of the volumetric wear rate is 1 . With an increase in the value of the standard deviation of the external action and the number of steps of change in the action, the coefficient of variation of the volumetric wear rate increases to values 2,59 , those volumetric wear rate increases by $1,125 \ldots 2,59$ times. This is confirmed by experimental dependencies. The simulation results are adequate to the experimental results with a confidence level 0,9. Calculated modeling error for each series of experiments, which does not exceed $11,03 \%$. It was found that when changing the power of the bully tribosystem $W_{b}$, which is defined as the product of the load and the sliding speed, the coefficient of variation of the volumetric wear rate increases by $1,25 \ldots 4,68$ times. Taking into account the range of changes in the external impact and the operating time at each stage of change in the impact will provide information in the form of a coefficient of increasing the wear rate.
\end{abstract}

Key words: tribosystem; dynamic processes; volumetric wear rate; load fluctuations; external influence on the tribosystem; wear rate increase factor, modeling of processes of friction and wear.

\section{Introduction}

Most of the tribosystems of various machines and mechanisms during operation are under dynamic loading (change in load and sliding speed in time), what affects the value of the wear rate. The reason for this is the processes of secondary running-in in tribosystems and their adaptation to new external influences. The processes of secondary running-in when changing the load and sliding speed cause an increase in the wear rate during transient processes, which increases wear and leads to a reduction in the tribosystem resource during operation. In work [1] obtained transient characteristics of tribosystem running-in, which allow to establish the interconnection between the tribosystem construction, rational loading conditions, running-in time and wear for running-in. The analysis of the given work allows us to conclude that changes in the external impact on the tribosystem during operation will always be accompanied by an increase in the wear rate.

Taking into account the above, this paper considers the issues of taking into account the increase in the volumetric wear rate of tribosystems in the presence of dynamic operating conditions, where the load and sliding speed changes with time taking into account the number of loading steps and the duration of operation at each loading step.

\section{Literature review}

The authors of the work [2] a three-dimensional finite element model has been developed to simulate the change in the friction coefficient under dynamic load on the tribosystem. Correction factor obtained, which can be used to correct the experimental data, which depends on the load fluctuation during the tribosystem 
operation. In work [3] the effect of increasing the load, as well as the duration of the tribosystem operation at each stage of the load, on the wear resistance of steels was studied. The authors found that the duration of operation at each stage is a significant factor affecting the wear resistance.

In work [4], on the basis of a mathematical model, various aspects of long-period oscillations of tribological parameters in the process of wear of metals under heavy load are theoretically investigated. The obtained dependence, which allows calculating the wear of the tribosystem by the parameters of load fluctuations. In work [5] a correlation is also established between the bearing loading parameters (load and sliding speed) and wear and tear resistance. It is concluded that when predicting the bearing life, the product of the load and sliding speed should be included in the calculation formulas.

The authors of the work [6] it is concluded that load fluctuations during tribosystem tests and a step change in load to the bully load, has a strong effect on wear resistance.

Based on the analysis of works devoted to the problem of wear under dynamic loading of tribosystems, it can be argued that the process of friction and wear is stochastic, where during operation the load and sliding speed change in time. Consideration of load fluctuations was carried out by the authors of the work [7], where, using the probabilistic approach, the coefficient of increase in the wear rate was obtained, which is equal to $1,6 \ldots 4,5$, compared to steady-state operation. However, the obtained dependencies do not take into account the time variable and even more the operating time at each load stage. In works $[8,9]$ the rationale for increasing the wear of the tribosystem materials under dynamic load changes is given, what is taken into account by special coefficients in the models. A similar approach is presented in the works [10 - 12], where loading conditions are estimated by 3D models.

Based on the analysis of works devoted to increasing the wear rate under dynamic impact on the tribosystem during operation, it can be concluded that to improve the accuracy of modeling the wear rate it is necessary to take into account the range of changes in the external influence and the operating time at each stage of the change in the influence. This approach will provide information in the form of a coefficient of increase in the wear rate in relation to the steady state, which will increase the accuracy of modeling and determining the resource of tribosystems in operation.

\section{Purpose}

The purpose of this study is to obtain a mathematical expression for modeling the processes of friction and wear when changing the external impact on the tribosystem, carry out experimental studies and confirm the reproducibility and adequacy of the obtained models to experimental data.

\section{Methods}

When developing a probabilistic model of increasing the volumetric wear rate during load fluctuations and sliding speed during testing or operation, as well as the number of steps of change, as an input parameter we will use the power that is supplied to the tribosystem and is determined by the expression:

$$
W_{i}=N_{i} \cdot v_{i} ;\left[N \cdot \frac{m}{s}=J / s=W\right]
$$

where $N_{i}$ - tribosystem load, N;

$v_{i}$ - sliding speed, $\mathrm{m} / \mathrm{s}$.

Based on the results of the experimental values, using the least squares method, regression equations in natural values were obtained, which have the following form:

- for the volumetric wear rate of the tribosystem at steady state:

$$
I=\frac{2,26 \cdot W_{T R}}{Q_{\max }} \cdot \exp \left(\frac{W_{i}}{W_{b}}\right), m^{3} / \text { hour },
$$

where $W_{T R}-$ speed of dissipation in the tribosystem, dimension $\mathrm{J} / \mathrm{s}$, determined according to work [7];

$Q_{\max }$ - quality factor of the tribosystem after the completion of running-in, dimension $\mathrm{J} / \mathrm{m}^{3}$, determined according to work [8];

$W_{b}$ - power value of friction at which begins the accelerated wear or bully (loss of stability of tribosystem), bully power, dimension $\mathrm{W}$.

Applying a methodical approach to work [1], we write down the expression for the volumetric wear rate when the external action on the tribosystem changes from $W_{i, \min }$ to $W_{i, \max }$. In this case, we will accept the assumption that the change in the external influence on the tribosystem obeys the normal distribution law: 


$$
\bar{I}_{\mathrm{var}}=\int_{W_{i, \min }}^{W_{i, \max }} I\left(\frac{W_{i}}{W_{b}}\right) \frac{1}{\sqrt{2 \pi} \sigma_{W}} e^{-\frac{\left(W_{i}-W_{a v}\right)^{2}}{2 \sigma_{W}{ }^{2}}} d W_{i},
$$

where $\sigma_{W}$ - root-mean-square deviation of external influence on the tribosystem $-\mathrm{W}$, defined by the expression:

$$
\sigma_{W}=\sqrt{\frac{1}{n} \sum_{i=1}^{n}\left(W_{i}-W_{a v}\right)^{2}}
$$

$n$ - the number of changes in the external influence on the tribosystem during the test;

$W_{a v}$ - average value of external influence on the tribosystem during the test, $\mathrm{W}$.

Given the expression (2) expression (3) can be written as follows:

$$
\bar{I}_{\mathrm{var}}=\int_{W_{i, \min }}^{W_{i, \max }} \frac{2,26 \cdot W_{T R}}{Q_{\max }} \cdot \exp \left(\frac{W_{i}}{W_{b}}\right) \cdot \frac{1}{\sqrt{2 \pi} \sigma_{W}} e^{-\frac{\left(W_{i}-W_{a v}\right)^{2}}{2 \sigma_{W}{ }^{2}} d W_{i}}
$$

After the performed transformations, the expression (5) can be written as follows:

$$
I_{\mathrm{var}}=\frac{2,26 \cdot W_{T R}}{Q_{\max }} \cdot \exp \left(\frac{W_{i}}{W_{b}}\right) \cdot k_{\mathrm{var}}, m^{3} / \text { hour } .
$$

where $k_{\text {var }}$ - coefficient of increase in the volumetric wear rate due to variations in external influences, loads and sliding speeds (coefficient of variation of volumetric wear rate).

\section{Results}

The coefficient of variation of the volumetric wear rate is determined by the expression:

$$
k_{\mathrm{var}}=\left[1+\frac{\sigma_{W}}{W_{b}} \cdot\left(\frac{t_{\exp l}}{t_{s t}}\right)^{\frac{\sigma_{W} / W_{b}}{1+\sigma_{W} / W_{b}}}\right]
$$

where $t_{\operatorname{expl}}$ - total test (exploitation) time of the tribosystem, s;

$t_{s t}$ - test time (exploitation) tribosystems at one stage, when the external influence does not change, s.

$\left(t_{\exp l} / t_{s t}\right)=n$ - the number of steps of changing the external influence on the tribosystem during the tests.

Let us simulate the change in the coefficient of variation of the volumetric wear rate when changing the load and sliding speed on the tribosystem, the formula (7), as well as the number of steps of change in the load $n$ and the operating time at each step $t_{s t}$.

From expression analysis (7) it follows that in the absence of fluctuations in the load and sliding speed during the tests, the standard deviation of the external influence $W_{i}$ from average $W_{a v}$ equal to zero, this follows from the expression (4). Therefore, for $\sigma_{W}=0$ coefficient of variation of volumetric wear rate $k_{\text {var }}$, according to expression (7), is equal to 1 . With an increase in the value of the standard deviation of the external influence and the number of steps of change in the influence, the coefficient of variation of the volumetric wear rate increases to values 2,59 , those volumetric wear rate increases by $1,125 \ldots 2,59$ times. This is confirmed by the dependences shown in fig. 1.

When changing the bully power $W_{b}$, which is defined as the product of the load and the sliding speed, the formula (1), the coefficient of variation of the volumetric wear rate increases by $1,25 \ldots 4,68$ times. This is confirmed by the dependences shown in fig. 2 .

Bully power $W_{b}$, or the product of load and sliding speed, formula (1), at which begins accelerated wear or bully, indirectly characterizes the combination of materials in the tribosystem with other factors unchanged. For example, the quantity $W_{b}=1000 \mathrm{~W}$ corresponds to the «ring-ring» tribosystem, $K_{f}=12,51 / \mathrm{m}$, material combination steel $40 \mathrm{H}+$ steel $40 \mathrm{H}, E_{u}=3,64 \cdot 10^{14} \mathrm{~J} / \mathrm{m}^{3}$. The quantity $W_{b}=1500 \mathrm{~W}$ corresponds to tribosystem «ring-ring», $K_{f}=12,51 / \mathrm{m}$, material combination steel $40 \mathrm{H}+\mathrm{SCh}, E_{u}=3,64 \cdot 10^{14} \mathrm{~J} / \mathrm{m}^{3}$.

The quantity $W_{b}=2000 \mathrm{~W}$ corresponds to tribosystem « ring-ring », $K_{f}=12,51 / \mathrm{m}$, material combination steel $40 \mathrm{H}+\mathrm{Br}$.AZh 9-4, $E_{u}=3,64 \cdot 10^{14} \mathrm{~J} / \mathrm{m}^{3}$. 


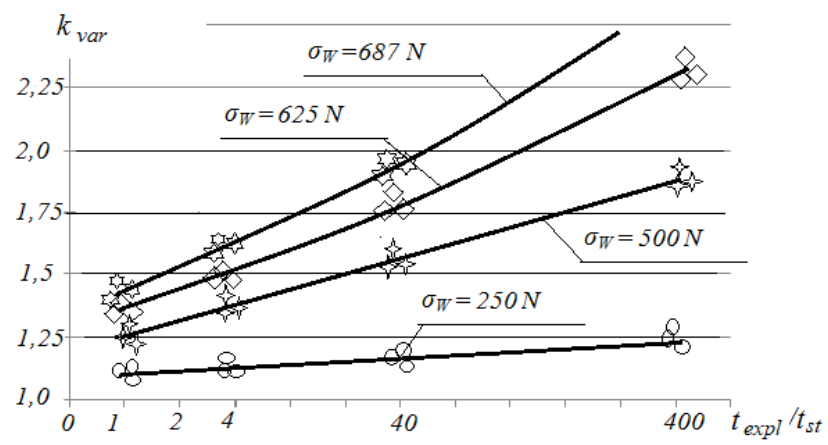

Fig. 1. Dependences of the change in the coefficient of variation of the volumetric rate of wear on the value of the standard deviation of the external influence and the number of steps of the external influence

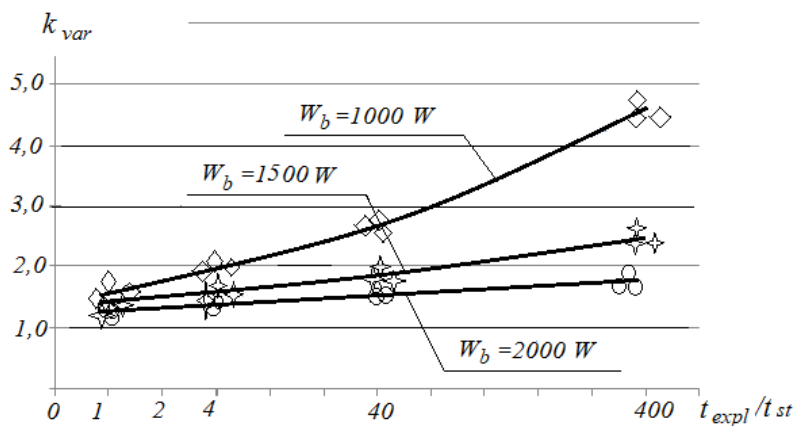

Fig. 2. Dependences of the change in the coefficient of variation of the volumetric wear rate on the magnitude

of the bully power and the number of steps of external influence

The obtained dependences of modeling the value of the coefficient of variation of the volumetric wear rate, presented in fig. 1 and fig. 2, were tested experimentally in laboratory conditions on a friction machine according to the scheme «ring - $\operatorname{ring} », K_{f}=12,51 / \mathrm{m}, F_{\min }=0,00015 \mathrm{~m}^{2}, F_{\max }=0,0003 \mathrm{~m}^{2}$.

The combination of materials in the tribosystems was chosen so as to provide different values of the bully power. The experimental results were checked for reproducibility by the Cochran test and their adequacy to theoretical curves by Fisher's test. The results of modeling the volumetric wear rate are adequate to the results of the experiment with a confidence level 0,9 . The simulation error is calculated for each series of experiments, which does not exceed $11,03 \%$, which can be considered satisfactory when studying the processes of friction and wear.

The obtained theoretical dependences are adequate to the experimental data and can be used to determine the increase in the volumetric wear rate of tribosystems during testing or operation, when the load and sliding speed change.

\section{Conclusions}

Expressions are obtained for modeling the processes of friction and wear when changing the external influence on the tribosystem. Modeling of the change in the coefficient of variation of the volumetric wear rate when changing the load and sliding speed on the tribosystem, as well as the number of stages of load change and operating time at each stage. It was found that in the absence of fluctuations in the load and sliding speed, the coefficient of variation of the volumetric wear rate is 1 . With an increase in the value of the standard deviation of the external action and the number of steps of change in the action, the coefficient of variation of the volumetric wear rate increases to values 2,59, those volumetric wear rate increases by $1,125 \ldots 2,59$ times. This is confirmed by experimental dependencies. The simulation results are adequate to the experimental results with a confidence level 0,9. The simulation error is calculated for each series of experiments, which does not exceed $11,03 \%$. It was found that when changing the bully power $W_{b}$, which is defined as the product of the load and the sliding speed, the coefficient of variation of the volumetric wear rate increases by 1,25 .. 4,68 times.

\section{References}

1. Vojtov V. A., Biekirov A. Sh., Voitov A. V. and Tsymbal B. M. 2019 Running-in procedures and performance tests for tribosystems, Journal of Friction and Wear, 40(5), pp. 376-383. DOI: 10.3103/S1068366619050192 [English] 
2. Jankowiak T., Rusinek A., List G., Sutter G., Abed F. Numerical analysis for optimizing the determination of dynamic friction coefficient // Tribology International Volume 95, 2015, Pages 86-94 https://doi.org/10.1016/j.triboint.2015.10.039 [English]

3. Yevtushenko A. A., Kuciej M., Yevtushenko O. O. Influence of the pressure fluctuations on the temperature in pad/disc tribosystem // International Communications in Heat and Mass Transfer Volume 37 , Issue 8, 2010, Pages 978-983 https://doi.org/10.1016/j.icheatmasstransfer.2010.06.011 [English]

4. Ivan I., Argatov Yury, Fadin A. Asymptotic modeling of the long-period oscillations of tribological parameters in the wear process of metals under heavy duty sliding conditions with application to structural health monitoring // International Journal of Engineering Science Volume 48, Issue 10, 2010, Pages 835-847 https://doi.org/10.1016/j.ijengsci.2010.05.006 [English]

5. Wojciechowski Ł., Mathia T. G. Focus on the concept of pressure-velocity-time (pVt) limits for boundary lubricated scuffing // Wear Volumes 402-403, 2018, Pages 179-186 https://doi.org/10.1016/j.wear.2018.02.019 [English]

6. Goto H., Amamoto Y. Improvement of wear resistance for carbon steel under unlubricated sliding and variable loading conditions // Wear Volume 270, Issues 11-12, 2010, Pages 725-736 https://doi.org/10.1016/j.wear.2010.12.010 [English]

7. Kordonskiy KH.B., Kharach G.M., Artamonovskiy V.P., Nepomnyashchiy Ye.F. Veroyatnostnyy analiz protsessa iznashivaniya. - M.: Izd-vo «Nauka», 1968, - 56 p. [Russian]

8. Kanarchuk V.Ye. Adaptatsiya materialov k dinamicheskim vozdeystviyam - K.: Naukova dumka, 1986. - 264p. [Russian]

9. Lapshin S.A. Rol' dinamicheskikh nagruzok v razvitii protsessa iznashivaniya //Zesz. nauk. AGH im.Stanislawa Staszica. Mech. - 1990.- №9, №2. - P.53-59. [Russian]

10. Ivshchenko L. I. Interpretatsiya rezul'tatov iznashivaniya pri slozhnom znakoperemennom nagruzhenii [Tekst] / Ivshchenko L.I., Tsyganov V.V. // Problemi tertya ta znoshuvannya. - 2011. - №56. - P. 45-55. [Russian]

11. Ivshchenko L.I. Strukturnaya samoorganizatsiya detaley tribosopryazheniy v usloviyakh slozhnogo termodinamicheskogo nagruzheniya [Tekst] / Ivshchenko L.I., Tsyganov V.V., Frolov M.V. //Vísnik CHDTU. Seríya «Tekhníchní nauki». - 2012. - №3(59) - P. 5-11. [Russian]

12. Ivshchenko L.I. Kontaktnaya zadacha mekhaniki razrusheniya tribosopryazheniy pri slozhnom termomekhanicheskom nagruzhenii [Tekst] / Ivshchenko L.I., Tsyganov V.V. //Matematichne modelyuvannya. 2013. - №2. - P.78-82. [Russian]

13. Vojtov V.A., Zakharchenko M.B. Modelirovaniye protsessov treniya iznashivaniya v tribosistemakh v usloviyakh granichnoy smazki. Chast' 1. Raschet skorosti raboty dissipatsii v tribosistemakh / Problemi tribologíi. - 2015. - № 1. - P. 49-57. [Russian]

14. Viktor Vojtov, Abliatif Biekirov, Anton Voitov The quality of the tribosystem as a factor of wear resistance // International Journal of Engineering \& Technology, 2018, Vol 7, № 4.3 P. 25-29. DOI: 10.14419/ijet.v7i4.3.19547 [English]

Войтов А.В. Моделювання процесів тертя та зношування при динамічних впливах на трибосистему.

На підставі виконаного аналізу робіт, присвячених збільшення швидкості зношування через динамічного впливу на трибосистем, отримані вирази для моделювання процесів тертя і зношування при зміні зовнішнього впливу. На підставі прийнятого допущення, що динамічний вплив підпорядковується нормальному закону розподілу, отриманий коефіцієнт варіації об'ємної швидкості зношування. Виконано моделювання зміни коефіцієнта варіації при зміні навантаження і швидкості ковзання на трибосистем, а також кількості ступенів зміни навантаження і часу роботи на кожному ступені.

Встановлено, що при відсутності коливань навантаження і швидкості ковзання коефіцієнт варіації об'ємної швидкості зношування дорівнює 1. 3 збільшення величини середньоквадратичного відхилення зовнішнього впливу і кількості ступенів зміни впливу, коефіцієнт варіації об'ємної швидкості зношування збільшується до значень 2,59, тобто об'ємна швидкість зношування збільшується в 1,125 ... 2,59 раз. Це підтверджено експериментальними залежностями. Результати моделювання адекватні результатами експерименту з довірчою ймовірністю 0,9. Розрахована похибка моделювання по кожній серії експериментів, яка не перевищує 11,03%. Встановлено, що при зміні потужності задира $W_{\text {зад}}$, яка визначається як добуток навантаження на швидкість ковзання, коефіцієнт варіації об'ємної швидкості зношування збільшується в $1,25 \ldots 4,68$ раз. Облік діапазону зміни зовнішнього впливу і часу роботи на кожному ступені зміни впливу дозволить отримати інформацію у вигляді коефіцієнта збільшення швидкості зношування. Отримані теоретичні залежності адекватні експериментальним даним.

Ключові слова: трибосистема; динамічні процеси; об'ємна швидкість зношування; коливання навантаження; зовнішній вплив на трибосистем; коефіцієнт збільшення швидкості зношування; моделювання процесів тертя та зношування. 